\title{
Determinants of Dividend Payout Policy of Listed Corporations in Nigeria
}

\author{
Peter E. Ayunku \\ Department of Banking and Finance, Niger Delta University, Wilberforce Island, Bayelsa State, Nigeria \\ Dumani Markjackson* \\ Department of Banking and Finance, Federal Polytechnic, Ekowe, PMB 110, Yenagoa, Bayelsa State, Nigeria
}

\begin{abstract}
This study examines the underlying components that determine the dividend policy statement of corporations in Nigeria. The study purposively select ninety-four (94) corporations out of the universe of companies listed in the Nigerian Stock Exchange. Financial ratios were extracted and computed from published annual audited financial reports spanning 2007 to 2017. This was informed by the ex-post facto research design adopted to observe key indicators of these corporations in retrospect. The panel regression analysis was used to explain the numerical phenomenon collated. The Durbin-Wu-Hausman specification test found the fixed effect model to be more suitable. The empirical results indicate that financial leverage has a significant negative impact on dividend payout; liquidity has an insignificant positive impact on dividend payout policy; profitability has an insignificant positive impact on dividend payout decision; and company size has a significant positive impact on dividend payout dicision. The study concluses that liquidity, profitability and company size are the determinants of the dividend policy of corporations in Nigeria. More specifically, company size was found to be a major determinant to the dividend policy statement of corporations in Nigeria. The study suggests that, corporations should sustain their liquid positions, asset base and profit levels at all times to meet the universe of desires of their shareholders.
\end{abstract}

Keywords: Dividend payout; Determinants; Corporations; Nigeria; Profitability; Liquidity.

(c) (f) CC BY: Creative Commons Attribution License 4.0

\section{Introduction}

The nucleus of every going concern is to maximize the wealth of the owners of the corporation. Faced with this, corporations are always faced with the decision of coming up with the most suitable proportion of external funding that would suffice this objective. To ensure this, it is the desire of every corporation to have an optimal capital structure that would maximize the value of the firm and at the same minimize its cost of capital. Debt capital tend to expose the firm to the risk of insolvency while equity capital breeds the dilemma of the proportion of profit to be paid out as dividend to its shareholders and retained funds to be ploughed back into the corporation. Profitability, historical dividend, liquidity, financial leverage and total asset size tend to exert influence on the decision to pay or not pay dividend by corporations.

Consequently, the decisions of firms relating to dividend policy have been a subject of debate in financial literatures. Financial managers are generally involved in various critical and important decisions such as investment portfolios, product development, and financing, with the goal of increasing the market value of the firm (Afza and Mirza, 2011). Academics and researchers have developed series of theoretical models and explanations describing the several factors that managers should consider when making decisions about dividend payout policy. In the context of this study, dividend policy is defined as the firm's dividend payout policy that managers follow in deciding the pattern and size of cash distribution to shareholders over time. It is important to note here that different companies have their specific policies as regards their dividend payout.

Following the work of Lintner (1956) and Miller and Modigliani (1961), dividend payout policy has remained one of the most controversial issues in corporate finance, and it has been listed as one of the top ten crucial unresolved issues in the world of finance (Brealey and Myers, 2005). Following the work of Miller and Modigliani (1961), series of academic research have been carried out on firms' dividend policy. Miller and Modigliani averred that firms' value is not determined by its dividend payout policy but is rather affected by the investment decisions of the firm under the assumption of certainty in the market. Gordon (1963), in presenting his Bird in Hand theory, negated the argument of Miller and Modigliani. Gordon (1963), posited that imperfect market information can influence shareholder wealth positively following an increase in dividends. Several other theories have been postulated, contributing to the ever increasing literature on dividend payout policy.

Despite the various theories and models on dividend payout policy postulated over the years, Black (1976) states that the concept of dividend payout policy has remained a puzzle because this concept has remained an unending puzzle, with pieces that just do not fit together. Some of the unanswered questions that have caused constant disagreements amongst researchers include: does dividend policy affect value? What are the factors that determine dividend policy? Is dividend policy determined dependently or independently? Consequently, this study set out to examine one of these three pertinent areas; which is to examine the determinants of dividend policy in select corporations in Nigeria. 
This is expedient because majority of empirical studies concentrated on the determinants of dividend policy in the banking sector, more especially the Nigerian banking sector, while a handful focused on other sectors. To the best of the researcher's knowledge, more attention on the determinants of dividend policy that cuts across sectors in Nigeria is still desired. On the premise that, the findings from previous studies also lack conclusive results. For instance, in Okoro et al. (2018) and Kaźmierska-Jóźwiaka (2015) studies, financial leverage was found to be an insignificant determinants of dividend policy, whereas, the studies by Ogundajo et al. (2019) and Moon et al. (2015) found finncial leverage to be a significant determinant of dividend payout. Other measures or determinants also showed divergent findings in different studies. This varid findings futher gives room to further examine the determinants of dividend policy (though in another sector with recent data) with the hypothesis that the empirical results may swing either way towards giving credence to one of the strands of conclusions in extant literature.

\subsection{Objectives of the Study}

The central objective of this study is to examine the determinants of dividend payout policy of quoted companies in Nigeria. The specific objectives of this study are:

1. To examine the impact of profitability on dividend payout policy of quoted companies.

2. To determine the impact of financial leverage on dividend payout policy of quoted companies.

3. To examine the impact of firm's liquidity on the dividend payout policy of quoted companies.

4. To evaluate the impact of the size of the company (total asset) on dividend payout policy of quoted companies.

\subsection{Significance of the Study}

Different stakeholder groups such as managers, lenders, investors, policy makers, investment analysts and researchers and academics are impacted by the dividend policy adopted by a firm. In particular, investors are concerned with the ability of the company to pay dividends. Investment involves the commitment of large sums of money, and potential investors are interested in the getting returns from their invested capital, which in this case, is the cash distribution policy of the company. The result of this study will, on the one hand, assist managers of corporations to determine the factor or combination of factors necessary for arriving at the size and pattern of cash distributions to shareholders over time.

Additionally, knowledge of the determinants of corporate dividend payout enables lenders to determine the level of risk attached to a borrower or potential borrower. Various studies have shown that dividend payments always favour the shareholders ahead of lenders/creditors. Thus, companies planning to access the credit markets frequently cut dividends to restore creditors' confidence and reflect a low level of agency cost of debt within the firm (Black and Scholes, 1973; Brockman and Unlu, 2009).

Despite the number of studies carried out on this topic since the 1950 s, there is still no consensus amongst researchers and this topic is still as confounding as it was in the beginning. This study is just another attempt to add to this growing body of knowledge for researchers, academics and managers to make reference to.

The rest of the paper is organized as follows; section 2 describes the theoretical framework, section 3 present reviews of related empirical studies, section 4 describes the methodology of the study, section 5 presents results and discussion of findings and section 6 concludes the study.

\section{Theoretical Framework}

Generally, there are two strands of arguments concerning dividend policy. There are those who posit that dividend payment is irrelevant and relevant in determining the value of the firm. Some of these theories are espoused to lay theoretical credence to the study.

Bird in Hand Theory - the theory holds that there is a positive nexus between dividend payout and the net worth a company. This is premised on the belief that investor groups see dividend payout less risky to gains accruing from retained earnings. This means that investors prefer consistent and increasing dividend payments, which invariably increase the share value of the company. Gordon (1959) and Lintner (1962) posit that the risk exposure of a company is a function of the inflows and outflows of funds and therefore could not be affected by the dividend payments.

Clientele Effect Theory: Central to this theory is that investor's penchant for the dividend policy of a firm is predicted on the tax bracket of the investor. Black and Scholes (1974), stated that the tax bracket of the investor group explains the fondness for dividend payments and profit retention. The theory posit that this has nothing to do with the value of the company nor its share price as investors would only invest in firms that have dividend policy that suits their prejudices.

Agency Theory - the divorce between those who owns and those who are charged with the day-to-day running of a company has sprout series of conflicts and costs to a firm. The owners of the company are shareholders (also known as principal), while the managers are regarded as agents to the principal. The conflict of interest and suspicion in this relationship is mostly as a result of information superiority mostly on the part of the manager and thus, the principal feel that the agent could short change him (Moon et al., 2015). Jensen and Meckling (1976), posit that dividend payment is relevant on the premise that dividend payouts reduce funds available to managers to push for their own agenda. This will help douse the conflict and suspicion between the stakeholder groups (Moon et al., 2015). 
Dividend Irrelevant Theory - this theory holds that shareholders are unconcern of whether dividend are paid or not at the end of the financial year since it does not determine the net worth or the price of its stocks. The theory supposes that the value of a firm is determined by the investment decision and its return potentials on the assumption of certainty. On this premise, Miller and Modigliani (1961) posit that dividend payments are irrelevant in optimizing the value of a firm. This means that investors would not pay extra premium for dividend payouts but rather could be disposed to pay extra premium based on the investment plans of the corporation.

\section{Review of Empirical Studies}

Okoro et al. (2018), examined the determinants of dividend policy of 9 consumer goods firms listed on the Nigerian Stock Exchange spanning 2006 to 2015. The study variables are dividend payout ratio (dependent variable), market value, profitability (esp), leverage, historical dividend (independent variables). The technique of analyses is multiple regression. The results report that market value and historical dividend has a positive and significant impact on dividend payment. Leverage and total asset (company size) reported a nonlinear and statistically insgnificant impact on dividend payments. Profitability (earnings per share) was found to be positive and exerted an insignifcant effect on dividend payout in the consumer goods subsector in Nigeria.

Jabbouri (2016), examined the determining factors of corporate divident payment in emerging market economies for a period spanning 2004 to 2013. The independent variables of the study are size, annual growth in assets (growth), total book value of debt divided by total assets (financial leverage), return on equity (current profit), earnings per share (future profit), past dividend (historical dividend), acid test ratio (liquidity), and book value of total asset, while the dependent variable is dividend pay-out ratio. Panel data analysis was used for the analysis. The results indicate that size, current profit, liquidity, and historical dividend have a positive and significant relationship with dividend pay-out ratio. Future profit was found to be positive but has an insignificant impact on dividend policy. It also emerged that growth, financial leverage, and book value of total asset have nonlinear and insignificant relationship with dividend policy in MENA countries.

Moon et al. (2015), investigated the determinants of dividend payment in the aviation sector. The sample population for was forty-six airlines spanning 2000 to 2012. The dependent variable is dividend payment and share repurchase while the explanatory vares are total assets (size), cash to total assets, leverage (total debt to total asset), return on assets, retained earnings to total asset (life cycle). Logistic regression was used for the analysis. It emerged that total asset (size), cash to total assets, leverage, and retained earnings to total asset has a positive impact on dividend payout. Also, it emerged that total asset (size), cash to total asset and retained earnings to total asset has a positive impact on share repurchase.

Kaźmierska-Jóźwiaka (2015), examined the determing factors that influence dividend payout in listed companies of Warsaw Stock Exchange in Poland spanning 2000 to 2012. The study variables are; dividend payout ratio (dividend per share to earnings per share) - dependent variable; financial leverage ratio (total debt to total assets), liquidity (current assets to currents liability), return on equity ratio (net profit to owners' capital), size (total assets), and future earnings (price of a share to earnings per share) - the explanatory variables. Panel data analytical technique was used for the estimation. Results show that there is a nonlinear and statistically insignificant relationship between return on equity and financial leverage on the dividend policy of the listed firms. Results also indicate that total asset (firm size) and future earnings has a positive but a statistically insignificant nexus with the dividend policy of the listed firms.

Odesa and Ekezie (2015), investigated the determinant of dividend payment in 131 listed companies in the Nigerian Stock Exchange. The study employed Financial leverage (total debt to total assets), return on equity, past dividend paid, shareholders structure, investment outlay as exogenous variables and dividend payout as the dependent variable. The data was analyzed using the multiple regression technique. Empirical results indicate that leverage, return on equity, stockholder structure, past dividend payments has a positive and significant impact on the dividend payment policy of the sample population. Investment outlay on the other hand, indicated a negative relationship.

Akani and Sweneme (2016), examined dividend policies of 14 manufacturing firms listed in the Nigerian Stock Exchange spanning 1981 - 2014. The study built two multiple regression models to identify the determinants of dividend policy these manufacturing companies. The dependent variables of the study are return on investment (ROI) and net profit margin; while the exogenous variables are dividend payout ratio, retention ratio, dividend yield, and earnings per share. Results from the models indicate that dividend yield has a negative relationship with return on investments and net profit margin. The results further indicate that dividend payout ratio, retention ratio, and earnings per share have a positive impact on returns on investment and net profit margin.

Funmilola et al. (2018), examined the impact of dividend payment on the profitability of 10 banks in Nigeria using a time scope spanning 2011 to 2015. Profit after tax was used to capture bank profitability and dividend per share and dividend payout ratio was used to capture the impact of dividend policy. The model was estimated using multiple regression technique. Results show that the proportion of dividend paid stimulates the profitability of banks. Dividend per share however, has no impact the profit after tax of banks.

Ogundajo et al. (2019), investigated how accounting information can be used to predict the investor's returns (dividend) of 36 manufacturing companies. The independent variables of the study are the lag of dividend, levarage, sales growth, earnings per share, operating cash flow and firm size, while the dependent variable is dividend payment. The panel fixed effect method was used to analyze the data set spanning 1997 to 2016. Lagged dividend, financial leverage and sale growth indicated the existence of a linear and significant impact with dividend payment. 
It also emerged that earnings per share, operating cash flow and size of the firm has a nonlinear relationship with dividend payout ratio.

Olowe and Moyosore (2014), set out to identify the factors that determine dividend payment of 20 bank qouted in the Nigerian Stock Exchange for the period covering 2006 to 2008. The proportion of dividend payout was used to capture dividend payments. The independent measures are profitability, liquidity, corporate tax, revenue growth, market to book value ratio, loan to deposit ratio, credit risk capital adequacy, activity mix, company size, cost income ratio, market power, debt to equity ratio and retained earnings. The data was pooled and estimated using multiple regression. The results indicate that bank liquidity, profitability, company size and activity mix as the determinants of dividend payments. Also, revenue growth, debt to equity ratio, retained earnings, the proportion loan to deposit and credit risks (loan loss provision to total loans) are not determinant dividend policy for the sample population of the study.

Hosain (2016), examined the determinants of dividend payments in 10 listed private banks in the Dhaka Stock Exchange Limited in Bangladesh. Data spanning 2005 to 2015 was collated and estimated using the duo of pooled ordinary least squares and the fixed effect panel technique. The measures of the study are dividend payout (dependent indicator), liquidity, company size, company risk, financial leverage, growth, previous year's dividends (historical dividend) and profitability (independent variables). The findings indicate that liquidity, growth and historical dividend have a significant positive impact of dividend payments. It also emerged that ownership structure, company size, financial leverage, the risk exposure level of the firms have a statistically insignificant influence on dividend payments of the sampled population.

Morakinyo et al. (2018), examined the dterminants of dividend policy of 15 banks listed in the NSE. The time scope of the study span 2006 to 2015, That is a 9 year interval. The dependent variable is dividend policy, while the independent variables are company size, leverage, profitability, board size, financial crises, political factor, and board independence. The data was analyzed and estimated using panel regression technique. The study report that company size and profitability (ROE) were found to positive. Financial leverage, board size, political factor and financial crisis dummies indicated a negative relationship with dividend policy. The size of the banks and political factor dummy was statistically significant, whereas all the other variables were found to be statistically insignificant.

Inyiama et al. (2015), set out to identify the determinants of the dividend policy of 2 brewery firms qouted in the Nigerian Stock Exchange. Specifically seek to detemine the impact of market price per share, total assets (firm size), net asset value per share, retained earnings and earnings per share on dividend per share. Data for the study span 2000 to 2013. The data was analyzed using the ordinary least sqaure technique. The estimates indicate that total asset (firm size) and net asset value per has a significantly nonlinear impact on dividend per share. Market price per share and earnings per stock showed a significantly linear relationship with dividend per share. The estimates also indicated that retained earnings have an insignificantly positive influence on dividend policy.

Sasona (2017), also examined the determinants of the dividend payout policy of 20 companies listed in the Nigerian Stock Exchange covering the period 2002 to 2016. The variables of the study are dividend payment ratio (endogenous variable), profitability, historical dividend, liquidity and the situation of the economy (explanatory measures). The numeric values collated were estimated using panel regression technique. The estimates reveal that aside historical dividend which indicated a significant impact on dividend payments; the other measures exerted an insignificant influence on dividend payments. Furthermore, the result indicated that profitability and past dividend payments have a positive influence on dividend payout ratio. Liquidity and state of the economy exerted a negative effect on dividend payment policy of the sampled companies studied.

Ranti (2013), seek to ascertain the determinant of dividend policy of 50 companies in the NSE. Data collated for the study span 2006 to 2011 on the indicators; profitability, size, leverage, board independence (as explanatory variables) and dividend payout (explained variable). The study employed the multiple regression technique for the estimation. The results showed that firm size (total asset) has statistically significant linear impact on dividend payments. Profitability (return on equity) indicate an insignificant positive influence on dividend payments. Futhermore, the estimates indicate that financial leverage exerts a significantly negative effect on dividend payout, while board independence plays an insignificant positive role in the dividend payment policy of the study sample population.

Rehman and Takumi (2012), examined the factors determing dividend policy of 50 firms listed in the Karachi Stock Exchange. To achieve this, the study collated data for debt to equity ratio, operating cash flow per share, profitability (ROE), market to book value ratio, current ratio and corporate tax on dividend payments. The data was analysed using the ordinary least square technique. The empirical results debt to equity ratio, profitability, liquidity, and corporate tax exerted a positive influence on dividend payments. The relationship between operating cash flow per share and market to book value ratio was found to be negative with dividend payout ratio. It also emerged that debt to equity ratio, profitability and market to book value ratio are the determinants of the dividend policies of the sampled companies.

The review covers cross country and country specific empirical studies. Also, some of the studies are sector specific while some cut across sectors. Majority of the studies revised concentrated on the determinants of dividend policy in the banking sector, more especially the Nigerian banking sector, while a handful focused on other sectors. To the best of the researcher's knowledge, more attention on the determinants of dividend policy that cuts across sectors in Nigeria is still desired. On the premise that, the findings from previous studies also lack conclusive results. For instance, in Okoro et al. (2018) and Kaźmierska-Jóźwiaka (2015) studies, financial leverage was found to be an insignificant determinants of dividend policy, whereas, the studies by Ogundajo et al. (2019) and Moon et al. (2015) found finncial leverage to be a significant determinant of dividend payout. Other measures or determinants 
also showed divergent findings in different studies. This varid findings futher gives room to further examine the determinants of dividend policy (though in another sector with recent data) with the hypothesis that the empirical results may swing either way towards giving credence to one of the strands of conclusions in extant literature.

\section{Methodology}

Aliaga and Gunderson (2000), Espoused that quantitative method explains a phenomenon by collecting numerical data that can be analyzed using statistical or other mathematical methods. The study therefore employed quantitative method in conjunction with the ex-post facto research design in order to have an in-depth understanding of the study as well as ensure quality and clarity of data that will be analyzed and also take into cognizance the avoidance of bias in presentation of findings.

\subsection{Source and Nature of Data}

Data for the study was collated via survey of existing documents. This secondary information was obtained from published annual audited accounts. The historical data comprises of time series and cross sectional data.

\subsection{Sample of the Study}

The purposive sampling technique was used to choose ninety-four (94) selected corporations out of the universe of corporations in Nigeria. The timeframe for the study span 2007 to 2017.

\subsection{Data Analysis Techniques}

Neumann (1997), defined data analysis as a search for patterns in data and also suggests that once a pattern is recognized, it is understood as a social theory or the setting in which it occurred. He also adds that a researcher moves from the description of a social setting to a more general interpretation of its meaning. Due to the combination of cross sectional and time series data, the appropriate method of analysis that will be used is panel data analysis. Panel data analysis was employed to determine whether profitability, financial leverage, liquidity, and company size predict the dividend payout ratio of firms in Nigeria.

The Hausman specification test was carried out on the data to determine whether the fixed effect (Ordinary Least Squares) regression estimates will be used or the Random Effect (Generalized Least Squares) regression analysis should be conducted.

\subsection{Model Specification}

Following extant empirical dividend policy studies, the model is built as follows;

$D P R_{i t}=c_{i}+q_{1} P F T_{i t}+q_{2} F I N L E V_{i t}+q_{3} L I Q_{i t}+q_{4} C S I Z E_{i t}+E_{i t}$

Where;

$\mathrm{q}_{1}$ to $\mathrm{q}_{4}$ are the coefficients of the explanatory variables, $\mathrm{c}$ is the constant, and $\mathrm{E}$ is the error term.

DPR is dividend payout ratio. It is calculated as dividend paid (payable) divided by profit before interests and taxes. DPR is the dependent variable of the model.

PFT is profitability. The measure of profitability used in this study is the return on equity (ROE). It is calculated as profit before interests and taxes divided by shareholders equity. PFT is an independent variable employed to explain its impact on dividend policy of the consumer goods sector.

FINLEV is financial leverage. It is calculated as debt to total assets. FINLEV is an independent variable employed to explain its impact on dividend policy of the consumer goods sector.

LIQ is liquidity. It is calculated as current assets minus current liabilities. LIQ is an independent variable employed to explain its impact on the dividend payout ratio of the consumer goods sector.

CSIZE is size of the company. It is represented by total assets. CSIZE is an independent variable employed to explain its impact on the dividend payout ratio of the consumer goods sector.

\section{Results and Discussion of Findings}

\subsection{Descriptive Statistics}

The descriptive statistics indicates the unique characteristics of the dataset.

Table-1. Descriptive statistics for the Variables of the Study

\begin{tabular}{l|l|l|l|l|l}
\hline & DPR & LEV & LIQ & PTF & CSIZE \\
\hline Mean & 2.637572 & 62.97745 & 5.751481 & 4.528025 & 16.75936 \\
\hline Median & 0.855000 & 62.41000 & 1.340000 & 5.425000 & 16.44500 \\
\hline Maximum & 60.85000 & 202.9900 & 456.8600 & 196.8000 & 22.28000 \\
\hline Minimum & 0.000000 & 8.300000 & 0.120000 & -696.4300 & 11.43000 \\
\hline Std. Dev. & 5.382014 & 23.70141 & 24.56831 & 38.86004 & 2.117682 \\
\hline Skewness & 5.192096 & 0.804801 & 13.83937 & -12.18422 & 0.417380 \\
\hline Kurtosis & 40.91619 & 6.179531 & 228.3359 & 219.8460 & 2.886537 \\
\hline Jarque-Bera & 62591.48 & 514.3597 & 2087467. & 1928448. & 28.74283 \\
\hline Probability & 0.000000 & 0.000000 & 0.000000 & 0.000000 & 0.000001 \\
\hline Sum & 2563.720 & 61214.08 & 5590.440 & 4401.240 & 16290.10 \\
\hline
\end{tabular}


Business, Management and Economics Research

\begin{tabular}{l|l|l|l|l|l}
\hline Sum Sq. Dev. & 28126.06 & 545465.9 & 586097.2 & 1466310. & 4354.525 \\
\hline Observations & 972 & 972 & 972 & 972 & 972 \\
\hline
\end{tabular}

The results indicate that the observations are equal. The mean values of the variables are; dividend payout ratio (2.637572), financial leverage (62.97745), liquidity (5.751481), profitability (4.528025), and company size (16.75936). The Jarque-Bera statistics indicate that all the variables are not normally distributed with statistically zero probability values. This indicates that the firms are unique and have different business profile. Aside profitability, the other variables are positively skewed.

The variance in the distribution is measured by the square root of variance. The results reveal as follows; dividend payout ratio (5.382014), financial leverage (23.70141), liquidity (24.56831), profitability (38.86004), and company size (2.117682). Dividend payments, profitability, liquidity and company size (total assets) are noticeably dispersed above the centre and the mean values while the financial leverage is noticeably dispersed below the centre and the mean, specifying that there is no large deviation of the numeric values from period to period.

\subsection{Hausman Test for Endogeneity}

The null hypothesis of the Hausman specification test holds that the random effect panel regression analysis is preferable, while fixed effect panel regression analysis is the alternate hypothesis. The rule of thumb is: accept the null hypothesis if the p-value is greater 5\%. This means that the null hypothesis is to be rejected and the alternate hypothesis is to be accepted if the p-value is less than $5 \%$.

Table-2. Summary Durbin-Wu-Hausman Specification Results

\begin{tabular}{|c|c|c|c|c|}
\hline \multicolumn{2}{|c|}{ Test Summary } & Chi-Sq. Statistic & Chi-Sq. d.f. & Prob. \\
\hline \multicolumn{2}{|c|}{ Cross-section random } & 26.795073 & 4 & 0.0000 \\
\hline \multicolumn{5}{|c|}{ Period Random Effects Test Comparisons } \\
\hline Variable & Fixed & Random & Var(Diff.) & Prob. \\
\hline LEV & -0.014525 & -0.013463 & 0.000003 & 0.5203 \\
\hline LIQ & 0.000209 & -0.000698 & 0.000001 & 0.2463 \\
\hline PTF & 0.000307 & 0.001873 & 0.000000 & 0.0003 \\
\hline CSIZE & -1.397490 & -0.693855 & 0.023145 & 0.0000 \\
\hline
\end{tabular}

The test statistics indicate that the chi square statistics of 26.795073 with a probability value that is statistically zero. This simply means that the fixed effect panel regression analysis is preferable and more appropriate for the analysis.

\subsection{Panel Regression Results}

The panel regression results using the fixed effect model are presented in table 3.

Table-3. The Fixed Effect Results

\begin{tabular}{|c|c|c|c|c|}
\hline \multicolumn{3}{|c|}{ Dependent Variable: DPR } & & \\
\hline \multicolumn{5}{|c|}{ Method: Panel Least Squares } \\
\hline \multicolumn{5}{|c|}{ Date: 08/14/19 Time: $11: 55$} \\
\hline \multicolumn{5}{|l|}{ Sample: 20072017} \\
\hline \multicolumn{5}{|l|}{ Periods included: 11} \\
\hline \multicolumn{5}{|c|}{ Cross-sections included: 94} \\
\hline \multicolumn{5}{|c|}{ Total panel (unbalanced) observations: 972} \\
\hline Variable & Coefficient & Std. Error & t-Statistic & Prob. \\
\hline LEV & -0.014525 & 0.006761 & -2.148327 & 0.0320 \\
\hline LIQ & 0.000209 & 0.004887 & 0.042868 & 0.9658 \\
\hline PTF & 0.000307 & 0.003058 & 0.100440 & 0.9200 \\
\hline CSIZE & 1.397490 & 0.218174 & 6.405375 & 0.0000 \\
\hline $\mathrm{C}$ & 26.97076 & 3.687554 & 7.313996 & 0.0000 \\
\hline R-squared & 0.720562 & \multicolumn{2}{|c|}{ Mean dependent var } & 2.637572 \\
\hline Adjusted R-squared & 0.689549 & \multicolumn{2}{|c|}{ S.D. dependent var } & 5.382014 \\
\hline S.E. of regression & 2.998757 & \multicolumn{2}{|c|}{ Akaike info criterion } & 5.129644 \\
\hline Sum squared resid & 7859.486 & \multicolumn{2}{|c|}{ Schwarz criterion } & 5.621595 \\
\hline Log likelihood & -2395.007 & \multicolumn{2}{|c|}{ Hannan-Quinn criter. } & 5.316877 \\
\hline F-statistic & 23.23410 & \multicolumn{2}{|c|}{ Durbin-Watson stat } & 2.305107 \\
\hline Prob(F-statistic) & 0.000000 & & & \\
\hline
\end{tabular}

The result from table $3 \mathrm{x}$-rays the possible determinants of dividend policies of selected companies in Nigeria. The adjusted coefficient of determination $\left(\mathrm{R}^{2}\right)$ indicated that the predictor variables explain about $0.689549(69 \%)$ of 
variation in the predicted variable. This means that $69 \%$ of changes in the dividend payout policy of select companies are caused by financial leverage, liquidity, profitability, and the size of these corporations (that is, total assets). This invariably means that the remaining $31 \%$ is explained by factors not captured in this study. The adjusted coefficient of determination further indicates that the model is adequately fitted. Furthermore, the Fisher-statistics reported the value, 23.23410 with a p-value that is statistically zero. This indicates that the entire model is statistically significant. More precisely, the predictor variables contribute significantly towards the determination of the dividend policy of corporations in Nigeria.

Specifically, the predictor variables suggest the following;

Financial leverage, an indicator of the trade on equity of corporations has a negative and statistically significant impact on dividend payout. This was indicated by the positive coefficient and the small p-value that is less than the $5 \%$ threshold. Extant literature holds that financial leverage could exert either a direct linear or nonlinear impact on the dividend policy of corporations (Okoro et al., 2018). It also holds that financial leverage elevate the risk exposure level of corporations when the ratio increases and thus exert a negative influence on dividend policy (Rozeff, 1982). This variable follows closely to economic theory and affirms that financial leverage has a nonlinear impact on the dividend policy of firms. This means that corporations that have a high debt to equity ratio are expected to be the least to pay dividend. This result follows closely with the empirical findings of KaźmierskaJóźwiaka (2015), (Jabbouri, 2016), Okoro et al. (2018), and Morakinyo et al. (2018). The following studies found that financial leverage has a positive impact on dividend payments Moon et al. (2015), Odesa and Ekezie (2015), and Ogundajo et al. (2019).

Liquidity, a measure of the liquid or cashholding of corporations indicates a statistically insignificant positive nexus with dividend payout policy of corporations. This was indicated by the positive coeffificent and high p-value that is above the 5\% threshold from the fixed effect model. This suggest that corporations who are highly liquid has the propensity to pay dividend. Although, this link according to this study is benign. This invariably means that corporations that are highly illiquid are more prone to retain and plough back the funds into the business. This result gives credence to the direct positive findings by Jabbouri (2016), Olowe and Moyosore (2014), Hosain (2016), and Rehman and Takumi (2012).

Profitability, an indicator of returns on shareholders funds indicates that there is a positive relationship between profitability and the dividend payout decision of corporations. Hoowever, this relationship was found to be insignificant; as indicated by a high p-value that is above the threshold. This invariable means that corporations with increasing returns on equity are more prone to pay cash dividend than firms with dwindling financial fortunes. This similarly means that profitability could be a huge determinant of the dividend policy of corporations. This result follow the empirical findings of positive nexus by Okoro et al. (2018), Ranti (2013), Olowe and Moyosore (2014), Rehman and Takumi (2012), and Jabbouri (2016). Some empirical studies affirm that profitability have a negative impact on dividend payment decision of corporations (see Kaźmierska-Jóźwiaka (2015); Ogundajo et al. (2019).

Company size, an indicator of the total asset position of corporations reveals that there is a statistically significant positive relationship beween the size of a corporation and the dividend payout dicision of corporations in Nigeria. This was indicated by the positive coefficient and the small p-value that is less than the 5\% threshold in the fixed effect model. This means that corporations with large asset portfolio are more disposed to declare cash dividends. More precisely, large corporations has high propensity to pay dividend than smaller firms. This result gives credence to the empirical findings of Jabbouri (2016), Moon et al. (2015), Kaźmierska-Jóźwiaka (2015), Olowe and Moyosore (2014), and Ranti (2013). In direct contrary, the findings by Ogundajo et al. (2019), Okoro et al. (2018), Hosain (2016), Inyiama et al. (2015) found the variable to be an insignificant determinant of dividend payments.

\section{Conclusion}

The paper set out to examine the determinants of dividend payment decision of corporations in Nigeria. Historical data was collated and analysed following the panel fixed effect example. The empirical results indicate that financial leverage has a negative and statistically significant impact on dividend payout; liquidity has a positive and statistically insignificant impact on dividend payout policy; profitability has a positive and statsitically insignificant impact on dividend payout decision; and company size has a positive and statistically significant impact on dividend payout dicision. The study concluses that liquidity, profitability and company size are the determinants of the dividend policy of corporations in Nigeria. The study found the total asset holdings of a company as a major determinant to the dividend policy of corporations in Nigeria. The study adds credence to the plethora of studies on the determinants of dividend payment decision of corporations and allude that firms that are profitable, liquid and has large total asset position are more prone to pay cash dividend than other corporations in Nigeria. It is worthy of note that corporations that have high trade on equity ratio has elevated risk exposure level, and thus, are more susceptible not to declare dividend to their shareholders. On this premise, the study suggests that, investors (especially aging investors and those that desire regular cash dividend payouts) should be abreast of the trade on equity ratio before investing in corporations. Corporations should also sustain their liquid positions, asset base and profit levels at all times to meet the universe of diverse desires of shareholders.

\section{References}

Afza, T. and Mirza, H. H. (2011). Do mature companies pay more dividends? Evidence from Pakistani stock market. Mediterranean Journal of Social Sciences, 2(2): 152-61. 
Akani, H. W. and Sweneme, Y. (2016). Dividend policy and the profitability of selected quoted manufacturing firms in Nigeria: An empirical analysis. Journal of Finance and Accounting, 4(4): 212-24.

Aliaga, M. and Gunderson, B. (2000). Interactive statistics. Saddle River New Jersey.

Black, F. (1976). The dividend puzzle. Journal of Portfolio Management, 2(2): 5-8.

Black, F. and Scholes, M. (1973). The pricing of options and corporate liabilities. Journal of Political Economics, 81(1): 637-54.

Black, F. and Scholes, M. S. (1974). The effects of dividend yield and dividend policy on common stock prices and returns. Journal Financial Economics, 1(1): 1-22.

Brealey, R. and Myers, S. (2005). Principles of corporate finance. McGraw-Hill: London. 155-67.

Brockman, P. and Unlu, E. (2009). Dividend policy, creditor rights, and agency cost of debt. Finance Department Faculty Publications.

Funmilola, Y. O., Adeniyi, A. A. and Abiodun, O. S. (2018). Dividend policy and banks' profitability in Nigeria. Nile Journal of Business and Economics, 4(10): 52-68.

Gordon, M. (1959). Dividends, earnings and stock prices. Review of Economics and Statistics, 41(2): 99-105.

Gordon, M. (1963). Optimal investment and financing policy. Journal of Finance, 18(2): 264-72.

Hosain, Z. (2016). Determinants of the dividend payout policy: A study on listed private commercial banks of dhaka stock exchange limited in Bangladesh. IOSR Journal of Economics and Finance, 7(5): 1-10.

Inyiama, C. E., Mary, O. and Inyiama, O. I. (2015). Dividend payout policy determinants of selected listed brewery firms in Nigeria: A meta-analysis 2000-2013. European Journal of Business, Economics and Accountancy, 3(3): 101-18.

Jabbouri, I. (2016). Determinants of corporate dividend policy in emerging markets: Evidence from MENA stock markets. Research in International Business and Finance, 37(C): 283-98.

Jensen, M. and Meckling, W. (1976). Theory of the firm: managerial behavior, agency costs and ownership structure. Journal of Financial Economics, 3(4): 305-60.

Kaźmierska-Jóźwiaka, B., 2015. "Determinants of dividend policy: Evidence from Polish listed companies." In 2nd Global Conference on Business, Economics, Management and Tourism, 30-31 October 2014, Prague, Czech Republic. 23,. Procedia Economics and Finance. pp. 473-77.

Lintner, J. (1956). Distribution of incomes of corporations among dividends, retained earnings and taxes. The American Economic Review, 46(2): 97-113.

Lintner, J. (1962). Dividends, earnings, leverage, stock prices and supply of capital to corporations. Rev. Econ. Stat., 44(3): 243-69.

Miller, M. H. and Modigliani, F. (1961). Dividend policy, growth, and the valuation of shares. The Journal of Business, 34(4): 411-33.

Moon, J., Lee, W. S. and Dattilo, J. (2015). Determinants of the payout decision in the airline industry. Journal of Air Transport Management, 42(C): 282-88.

Morakinyo, F. O., David, J. O., Adeleke, E. O. and Omojola, S. O. (2018). Determinants of dividend policy of listed deposit money banks in Nigeria. World Journal of Finance and Investment Research, 3(1): 25-40.

Neumann, W. L. (1997). Social research methods, qualitative and quantitative approaches. 3rd ed edn: Allyn and Bacon: Boston.

Odesa, J. O. and Ekezie, A. (2015). Determinants of dividend policy in quoted companies in Nigeria. Communication Panorama African and Global Perspectives, 1(1): 1-13.

Ogundajo, G. O., Enyi, P. E., Akintoye, I. R. and Dada, S. O. (2019). Accounting information and dividend payout prediction in nigerian listed manufacturing firms. Journal of Accounting and Taxation, 11(1): 9-16.

Okoro, C. O., Ezeabasili, V. and Alajekwu, U. B. (2018). Analysis of the determinants of dividend payout of consumer goods companies in Nigeria. Annals of Spiru Haret University, Economic Series, 1(1): 144-65.

Olowe, R. A. and Moyosore, S. L., 2014. "Determinants of dividend payout in the Nigerian banking industry." In Proceedings of 9th Annual London Business Research Conference, Imperial College, London. pp. 1-23.

Ranti, U. O. (2013). Determinants of dividend policy: A study of selected listed firms in Nigeria. Manager Journal, Faculty of Business and Administration, University of Bucharist, 17(1): 107-19.

Rehman, A. and Takumi, H. (2012). Determinants of dividend payout ratio: Evidence from Karachi stock exchange KSE. Journal of Contemporary Issues in Business Research, 1(1): 20-27.

Rozeff, M. S. (1982). Growth, beta and agency costs as determinants of dividend payout ratios. Journal of Financial Research, 5(3): 249-59.

Sasona, S. J. (2017). Determinants of dividend payout policy of Nigerian quoted companies. Master's Thesis, Redeemer's University. Department of Financial Studies: Ede. 